University of Nebraska - Lincoln

DigitalCommons@University of Nebraska - Lincoln

Nutrition and Health Sciences -- Faculty

Publications

Nutrition and Health Sciences, Department of

2010

Research Methodology for Validation of Nutrition Diagnostic

Standardized Language Using Fehring Models

Paula K. Ritter-Gooder

Nancy M. Lewis

University of Nebraska--Lincoln, nlewis2@unl.edu

Follow this and additional works at: https://digitalcommons.unl.edu/nutritionfacpub

Part of the Dietetics and Clinical Nutrition Commons

Ritter-Gooder, Paula K. and Lewis, Nancy M., "Research Methodology for Validation of Nutrition Diagnostic Standardized Language Using Fehring Models" (2010). Nutrition and Health Sciences -- Faculty

Publications. 8.

https://digitalcommons.unl.edu/nutritionfacpub/8

This Article is brought to you for free and open access by the Nutrition and Health Sciences, Department of at DigitalCommons@University of Nebraska - Lincoln. It has been accepted for inclusion in Nutrition and Health Sciences - Faculty Publications by an authorized administrator of DigitalCommons@University of Nebraska - Lincoln. 
Published in Journal of the American Dietetic Association, Volume 110, Issue 9, Supplement 1 (ADA Food \& Nutrition Conference \& Expo), September 2010, p. A79; doi:10.1016/j.jada.2010.06.298 Copyright ( 2010 Arthroscopy Association of North America; published by Elsevier Inc. Used by permission.

Published online August 18, 2010; poster presented at ADA Food \& Nutrition Conference \& Expo, Monday, November 8, 2010.

\title{
Research Methodology for Validation of Nutrition Diagnostic Standardized Language Using Fehring Models
}

\author{
P. K. Ritter-Gooder and N. M. Lewis \\ Department of Nutrition and Health Sciences, University of Nebraska-Lincoln, Lincoln, NE
}

Learning Outcome: Describe content validation process for refining standardized language diagnostic terms.

Validation of the nutrition standardized language (SL) confirms the language is accurate for use in practice, research, and policy. Nutrition diagnostic terms are identified by concept analysis using literature review and experts to distinguish and differentiate one nutrition problem from a similar or related problem. The Fehring models, used in nursing diagnosis validation research, are adopted to validate the SL nutrition diagnostic terms using experts and weighted inter-rater reliability ratios. In the first phase of validation research, diagnostic terms are validated by experts using the Diagnostic Content Validity Model (DCV). A Nutrition Diagnosis Validation Instrument (NDVI) is developed that contains the definition, etiologies, and signs and symptoms (s/s) of the diagnosis plus items added from literature review. Questions regarding clarity and completeness of the term are included. The NDVI uses a Likert-type scale with assigned weights to derive a DCV score. Using the weighted mean score, each item is classified into major $(\geq 0.80)$, minor (0.50 to 0.79 ), or non- relevant (below 0.49 ) characteristics. The Clinical Diagnostic Validation Model (CDV) is employed in the second phase to validate the term in the clinical setting observing patients with the nutrition problem using the NDVI, expert dietitians and a CDV score. Use of the DCV and CDV Models provides clear, comprehensive and observable lists of defining s/s needed for accurate and valid SL diagnostic terms and allows comparisons between studies. 